\title{
THE ECONOMIC LOSS DOCTRINE: A RECOMMENDATION FOR THE SUPREME COURT OF PENNSYLVANIA
}

\author{
Laura A. Wagner*
}

\section{INTRODUCTION}

The Supreme Court of Pennsylvania should adopt the economic loss doctrine to create a clear rule for the distinction between contract and tort claims, specifically in cases of products liability. This distinction is crucial when a purchased product malfunctions, causing damage not only to itself but also to people or other property. The Supreme Court of Pennsylvania has not yet reviewed a case that would clearly create a rule in the Commonwealth for distinguishing between tort and contract claims in the sale of goods. The Third Circuit has predicted that the Supreme Court of Pennsylvania would accept the economic loss rule as adopted by the Supreme Court of the United States. ${ }^{1}$ However, the Superior Court of Pennsylvania has predicted that the same court will accept the "gist of the action" doctrine. ${ }^{2}$ To further complicate this issue, the District Court for the Eastern District of Pennsylvania has suggested that the Supreme Court of Pennsylvania would adopt both rules for different situations. ${ }^{3}$ This has resulted in a number of lower courts taking opposing views when addressing this question.

This level of uncertainty calls for the Supreme Court of Pennsylvania to render a decision on the issue. In addition to confusion and lack of precedent, there are many practical reasons for why this distinction is necessary. The first and most obvious is the fact that tort and contract claims have different statutes of limitation. Under Pennsylvania law, the statute of limitations for contracts is four years, while tort actions only have an allowance of two years. ${ }^{4}$ An unclear distinction between contract and tort claims in products liability actions may result in litigation to determine if the statute bars certain claims instead of the litigants knowing this answer before the claim is

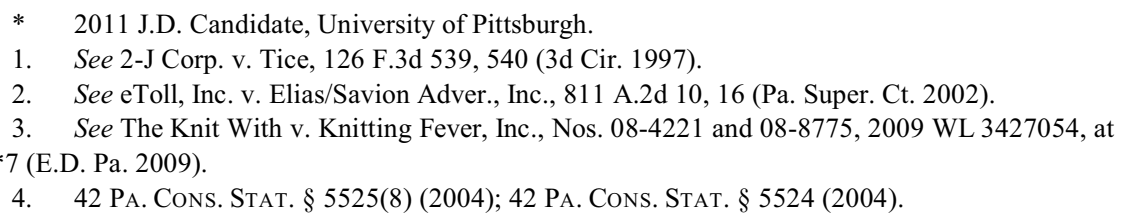


brought. ${ }^{5}$ The Supreme Court of Pennsylvania must decide this issue, if for no other reason than to make clear which types of actions fall under contract or tort in order to allow for proper filing guidelines for plaintiffs. Until this question is answered, the unclear standard by which courts currently distinguish between contract and tort claims may disadvantage plaintiffs who assume that their claim falls under one form of action or the other. For example, a plaintiff may file a contract claim against the defendant, filing within the statute of limitations for such a claim, but under the confusing Pennsylvania standard, the claim may be re-characterized as a tort, and as a result, barred by the limitations period. Adopting a clear rule for distinguishing between tort and contract claims will prevent problems such as this, and stop claims from being dismissed based on technicalities that could have been prevented by a more predictable rule.

This distinction between contract and tort is also essential in cases involving insurance companies when they are assessing a case for whether or not a duty to defend exists. ${ }^{6}$ Insurance companies for sellers and manufacturers may provide general liability coverage that only covers tort claims. A plaintiff may be denied coverage for high-cost claims and legal fees incurred through claims filed as torts because a Pennsylvania court finds the claim to be based in contract. ${ }^{7}$ This difficulty is only compounded when litigation takes place in a different state, especially one following the economic loss doctrine, and a negligence claim is pleaded, only to be re-characterized as a contract claim in Pennsylvania. ${ }^{8}$ This may lead to large financial losses by a company, not because of a failure to follow procedure, but rather because it is unclear whether the claim in question will be covered by its insurance policy. ${ }^{9}$ Making this standard more clearly defined will allow claims to be settled more easily, as manufacturers and sellers will then know whether litigation costs will be covered by their insurance policies.

A majority of the highest courts in other United States jurisdictions have chosen to follow some form of the economic loss doctrine. Many have chosen to follow two landmark Supreme Court cases that outline this rule. ${ }^{10}$ In doing so, these courts have adopted a clear standard for drawing the distinction

5. See generally Harleysville Homestead, Inc. v. Lower Salford Twp. Auth., 980 A.2d 749 (Pa. Commw. Ct. 2009).

6. See generally Erie Ins. Exch. v. Abbott Furnace Co., 972 A.2d 1232 (Pa. Super. Ct. 2009).

7. Id.

8. Id.

9. Id.

10. East River S.S. Corp. v. Transamerica Delaval Inc., 476 U.S. 858 (1986); Saratoga Fishing Co. v. J.M. Martinac \& Co., 520 U.S. 875 (1997). 
between tort and contract claims in products liability cases. While some state courts have made minor variations to the rule, each follows the general, critical distinction between what constitutes a tort and what constitutes a contract claim. By looking at each variation of the economic loss doctrine in other jurisdictions, it can be determined which approach would be most appropriate for Pennsylvania courts to adopt in order to create a clear standard, while continuing to fulfill the policy concerns which have fueled current lower court decisions.

This article covers the economic loss doctrine as addressed by the Supreme Court of the United States and the highest state courts for all fifty states, as well as the District of Columbia. It will focus on contracts for the sale of goods and products liability claims for when those products fail. Specifically, it will look to cases where a product causes damage, whether this results in personal injury or property damage either to the product itself or to other property. In this analysis, it will be necessary to determine what the proper definition of the "product" and "other property" should be when applying the economic loss doctrine. In the recommendation section, this paper will discuss which of these approaches will be best suited for Pennsylvania courts based on the policies listed in earlier decisions. Certain provisions of the Pennsylvania Uniform Commercial Code will be interpreted to address the policy considerations of the Commonwealth. ${ }^{11}$

\section{THE ECONOMIC LOSS DOCTRINE}

Seely v. White Motor Company has often been credited as the starting point for the economic loss doctrine. ${ }^{12}$ This case involved the sale of a truck that later malfunctioned and flipped, with the plaintiff seeking damages to cover the costs of repair, purchase price, and lost profits. ${ }^{13}$ Looking to the law of torts and warranties, the court held that "[e]ven in actions for negligence, a manufacturer's liability is limited to damages for physical injuries and there is no recovery for economic loss alone." "Physical injury" included both personal injury and damage to the plaintiff's other property aside from the truck itself. ${ }^{15}$ Economic losses are often defined as "disappointed economic

11. 13 Pa. Cons. Stat. $\S ~ 2313-18$ (2004).

12. Seely v. White Motor Co., 403 P.2d 145 (Cal. 1965) (en banc).

13. Id. at $147-48$.

14. Id. at 151 .

15. Id. at 152 . 
expectations." ${ }^{.16}$ Economic loss can also be defined as "the diminution in the value of a product and consequent loss of profits because the product is inferior in quality and does not work for the general purposes for which it was manufactured and sold." 17

The Supreme Court of the United States has adopted the economic loss doctrine in two landmark cases. In East River Steamship Corp. $v$. Transamerica Delaval Inc., the Court held that a defective product that only caused injury to itself would allow for claims of breach of contract exclusively. ${ }^{18}$ Specifically, the court characterized losses "resulting . . due to repair costs, decreased value, and lost profits" to be "essentially the failure of the purchaser to receive the benefit of its bargain." 19 These types of losses are those that the buyer can prepare and bargain protection for at the time of the contract. Contract recovery would put the buyer back in the position it would have been in had the product functioned properly. However, this recovery may be insufficient if there is personal injury or damage to other property, which is an issue addressed by the "other property" exception to the doctrine.

Over ten years after the East River decision, the Supreme Court addressed the issue of what should constitute "other property" for purposes of the tort/contract distinction. In Saratoga Fishing Co. v. J.M. Matinac \& Co., ${ }^{20}$ "other property" was defined as anything other than the product that was originally sold. Anything added to the product, even if foreseeable, is "other property" for the purposes of the economic loss doctrine. ${ }^{21}$ Damage to that "other property" as a result of the product's malfunction will then allow for tort recovery. ${ }^{22}$ This definition is often the issue that state courts have differed on, to be discussed in the jurisdictional survey.

States following these rulings have given a clear standard to both manufacturers and buyers who could then have a better understanding of future consequences, including the availability and preclusion of tort claims. Knowing whether certain injuries would allow for recovery in tort would encourage parties to include provisions that could protect their rights when

16. Airport Rent-A-Car, Inc. v. Prevost Car, Inc., 660 So. 2d 628, 630 (Fla. 1995) (citing Casa Clara Condo. Ass'n v. Charley Toppino \& Sons, Inc., 620 So. 2d 1244, 1246 (Fla. 1993)).

17. Gunkel v. Renovations, Inc., 822 N.E.2d 150, 154 (Ind. 2005) (citing Reed v. Cent. Soya Co., 621 N.E.2d 1069, 1074 (Ind. 1993)).

18. 476 U.S. 858 (1986).

19. Id. at 870 .

20. 520 U.S. 875 (1997).

21. Id. at $884-85$.

22. Id. at 877 . 
certain categories of harm are not covered by this doctrine..$^{23}$ This protection may also allow for the purchase price to be adjusted based on the kind of relief that would later be available to the buyer. The economic loss doctrine also allows for a clear distinction between tort and contract claims in litigation, providing more clearly defined rules for filing guidelines and more predictable results, which may encourage settlements.

\section{CURRENT State of PENNSYLVANIA LAW}

Pennsylvania courts do not currently have a clear rule for distinguishing between contract and tort claims. As the Supreme Court of Pennsylvania has not decided this issue, the lower courts have made rulings directly in opposition to each other. While certain cases have accepted the economic loss doctrine, others have followed the much more confusing "gist of the action" doctrine. This has resulted, not only in conflicting decisions within the state court system, but also in problems with decisions from other jurisdictions.

Under Pennsylvania law, the "gist of the action" doctrine distinguishes contract and tort claims by determining whether the claim "sounds" in contract or tort. ${ }^{24}$ A recent explanation of this approach is found in Erie Insurance Exchange v. Abbott Furnace Co., decided by the Superior Court in $2009 .{ }^{25}$ In summary, the defendant, a Pennsylvania corporation, sold a furnace to the plaintiff Innovative Magnetics, Inc. ("IMI"), a New Jersey company. ${ }^{26}$ The furnace later malfunctioned, causing harm not only to the furnace itself, but also to laminates passing through it. IMI brought suit in the New Jersey District Court for breach of contract and negligence, among other claims. Following this suit, Abbott filed a claim with Erie Insurance, its general liability coverage provider, for reimbursement stemming from the latter's duty to defend. Erie Insurance Exchange refused coverage, stating that the general liability plan covered only claims for torts, referred to as "occurrences," not mere breach of contract claims. ${ }^{27}$ Abbott argued that a negligence claim was

23. See, e.g., Lord v. Customized Consulting Specialty, Inc., 643 S.E.2d 28, 30 (N.C. Ct. App. 2007) ("[T] $[$ he rule encourages contracting parties to allocate risks for economic loss themselves, because the promisee has the best opportunity to bargain for coverage of that risk or of faulty workmanship by the promisor.").

24. Erie Ins. Exch., 972 A.2d 1232.

25. Id.

26. Id. at 1234 .

27. Id. at 1235 . 
pled in the original case in New Jersey, allowing for coverage under the plan. $^{28}$

The Superior Court held in Erie Insurance Exchange that the original suit did not include a proper negligence claim. ${ }^{29}$ It based this conclusion on the "gist of the action" doctrine, turning on "whether the 'gist' or gravamen of [the claim] sounds in contract or tort." 30 To make this determination, the court examined "the nature of the action as a whole," eventually finding that "[t]his [was] not a situation in which the tortious conduct was the 'gist' of the action and the contract was merely collateral to the conduct." ${ }^{31}$ Instead, the damage to the laminates "resulted from [Abbot's] contractual breach in failing to design the furnace in accordance with IMI's requested needs and intended use." 32 Since the court held that this was merely a contractual breach, Erie Insurance had no duty to defend, as the claim did not fall under Abbott's policy. ${ }^{33}$ The Supreme Court of Pennsylvania has since denied Abbott's appeal on this decision. ${ }^{34}$

Despite this seemingly unclear standard, the "gist of the action" doctrine is meant to distinguish between claims in contract and those in tort. This furthers the policy of disallowing plaintiffs to sue for hefty sums through tort claims when there is nothing more than a contractual breach. ${ }^{35}$ The Superior Court recently defined what it saw as the differences between contract and tort law coverage. While contract claims arise from "breaches of duties imposed by mutual consensus agreements between particular individuals," tort claims stem from "breaches of duties imposed by law a matter of social policy." 36 More specifically, the "gist of the action" doctrine will limit claims to contract when "the parties' obligations are defined by the terms of the contract, and not by the larger social policies embodied by the law of torts." ${ }^{37}$ This doctrine then focuses on the duty owed between the parties and whether a breach of this duty sounds in contract, or if the harm allows for tort recovery.

\footnotetext{
28. Id. at 1237.

29. Id. at 1239 .

30. Id. at 1238 (citing Pa. Mfrs.' Ass'n Ins. Co. v. L.B. Smith, Inc., 831 A.2d 1178, 1182 (Pa. Super. Ct. 2003)).

31. Id. at $1238-39$.

32. Id. at 1239 .

33. Id.

34. Erie Ins. Exch. v. Abbott Furnace Co., 987 A.2d 161 (Pa. 2009).

35. The Knit With, 2009 WL 3427054.

36. Erie Ins. Exch., 972 A.2d at 1238 (citing Reardon v. Allegheny College, 926 A.2d 477, 486-87 (Pa. Super. Ct. 2007)).

37. Id. at 1239 (citing eToll, Inc., 811 A.2d at 14).
} 
In applying the "gist of the action" doctrine, courts have also applied a misfeasance/nonfeasance test to distinguish between contract and tort claims. If it is determined that there has been "misfeasance," namely that "there is an improper performance of the contract in the course of which breaches a duty imposed by law as a matter of social policy," the plaintiff may bring a tort claim. ${ }^{38}$ Cases of "nonfeasance" are those in which "the wrong attributed to the defendant is solely a breach of the defendant's duty to perform under the terms of the contract." ${ }^{\prime 39}$ In these cases, the claim would sound in contract and no tort remedy may be claimed. These tests only further the confusion created by this doctrine.

The Third Circuit has taken a completely different approach when it addressed similar circumstances in 2-J Corporation $v$. Tice. ${ }^{40}$ The plaintiff in this case filed both tort and breach of contract claims for the collapse of a warehouse it had purchased, resulting in the destruction of items inside of it. ${ }^{41}$ The Third Circuit predicted that the Supreme Court of Pennsylvania would adopt the economic loss doctrine, thereby disallowing tort claims "for negligence or strict liability where the only injury was 'economic loss' - that is, loss that is neither physical injury nor damage to tangible property." ${ }^{, 2} \mathrm{In}$ reaching this conclusion, the Third Circuit cited the previously discussed cases decided by the Supreme Court of the United States. ${ }^{43}$ Based on these cases, the court held that both tort and contract claims were permissible in this particular case due to the damage to property other than the product itself. ${ }^{44}$ Additionally, a Pennsylvania Superior Court case also predicted that the Supreme Court of Pennsylvania would adopt the economic loss doctrine. ${ }^{45}$ Other panels of the Superior Court have even adopted it themselves. ${ }^{46}$

These cases demonstrate the need for a final decision on the distinction between tort and contract in products liability cases. The state of the law in Pennsylvania is highly confusing and allows for little to no predictability. The Pennsylvania Supreme Court could choose to adopt the "gist of the action"

38. Harleysville Homestead, Inc., 980 A.2d at 753 (citing Yocca v. Pittsburgh Steelers Sports, Inc., 806 A.2d 936, 944 (Pa. Commw. Ct. 2002)).

39. Id. (citing Yocca, 806 A.2d at 944$)$.

40. 126 F.3d 539 .

41. Id. at $540-41$.

42. Id. at 541 .

43. East River S.S. Corp., 476 U.S. 858; Saratoga Fishing Co., 520 U.S. 875.

44. 2-J Corp., 126 F.3d at 544.

45. REM Coal Co. v. Clark Equip. Co., 563 A.2d 128 (Pa. Super. Ct. 1989) (holding that tort claims are only available in cases where a defective product causes damage to other property).

46. Debbs v. Chrysler Corp., 810 A.2d 137 (Pa. Super. Ct. 2002). 
doctrine. However, even when all steps and exceptions to the doctrine are explained individually, it is not the most clear or predictable standard, and does not give enough guidance to courts in Pennsylvania. The court should instead adopt a form of the economic loss doctrine. Although there are many variations to this doctrine, each is generally based on the approach used by the Third Circuit. ${ }^{47}$ The following section will go through each form of this rule to determine which standard is the clearest and easiest to follow. In addition to the adoption of the economic loss doctrine, the court would have to choose an approach to the "other property" distinction to decide what type of damage would allow for tort recovery. Doing so will not only provide the lower courts with a clearer precedent, but will also allow parties to know what remedies are available to them. This will assist buyers and sellers in negotiating contracts with more appropriate protections to cover future damages. Finally, it may result in less litigation and more settlements because of the predictability of what may result at trial.

\section{JURISDICTIONAL SURVEY}

The majority of jurisdictions in the United States have chosen to follow the economic loss doctrine. While most courts have chosen to follow the framework laid out by the Supreme Court of the United States, others have adopted the doctrine with a slightly different definition. These variations often center on how a "product" should be defined in order to distinguish it from "other property." Certain jurisdictions have also adopted exceptions to the rule, allowing for tort recovery for damage to the purchased product in limited situations. Finally, a handful of states have chosen either not to address this issue or to reject the doctrine entirely.

\section{ECONOMIC LOSS DOCTRINE}

Many state courts have adopted what will be referred to as the "standard" economic loss doctrine as followed by the Supreme Court of the United States, with a large number of courts citing to East River directly. In order both to give a geographic perspective and to not lose information in excessively long notes, it will be advantageous to separate the states' holdings based on circuits. However, the circuit courts themselves will not be included, as their application is often of state law and will only confuse the numbers on 
jurisdictional choices. It should be noted that the cases used in this article are only those from the highest court of each state and apply only to products liability unless explained otherwise. While some states will use an exception to the economic loss doctrine in cases of professional liability, these cases are excluded from this survey.

All states within the First Circuit have adopted the economic loss doctrine without any major exception. ${ }^{48}$ The same is true of the Second Circuit. ${ }^{49}$ In the Third Circuit, both New Jersey and Delaware have accepted the standard rule, with Pennsylvania obviously choosing not to address the question as of this time.$^{50}$ In the Fourth Circuit, only South Carolina and Virginia have adopted the majority rule without exception. ${ }^{51}$ Similar to the law followed by the Fifth Circuit, Texas has adopted the standard form of the economic loss doctrine. ${ }^{52}$ While numerous appellate cases in Mississippi have also chosen to follow this theory, its highest court has not yet reviewed this question..$^{53}$ As is typical, due to the civil law roots of Louisiana, the courts of that state have not chosen to follow the path of the Fifth Circuit.

A majority of states within the Sixth Circuit follow the standard rule with the exception of Ohio, which adopts the general concept of the rule, but defines economic loss in a way that places it outside of the scope of the economic loss doctrine as established by the Supreme Court. ${ }^{54}$ Two of the three states in the Seventh Circuit have chosen to follow the "standard" economic loss doctrine. ${ }^{55}$ A majority of states in the Eighth Circuit follow the

48. Oceanside at Pine Point Condo. Owners Ass'n v. Peachtree Doors, 659 A.2d 267 (Me. 1995); Herbert A. Sullivan, Inc. v. Utica Mut. Ins. Co., 788 N.E.2d 522 (Mass. 2003); Franklin Grove Corp. v. Drexel, 936 A.2d 1272 (R.I. 2007); Kelleher v. Marvin Lumber and Cedar Co., 891 A.2d 477, 495 (N.H. 2005).

49. 532 Madison Ave. Gourmet Foods, Inc. v. Finlandia Ctr., Inc., 750 N.E.2d 1097, 1101 (N.Y. 2001); Travelers Ins. Cos. v. Demarle, Inc., 878 A.2d 267, 269 (Vt. 2005) (recognizing Superior Court's decision to bar negligence claims in products liability case); Flagg Energy Dev. Corp. v. GMC, 709 A.2d 1075,1088 (Conn. 1998) (referring to economic loss as "commercial loss").

50. Alloway v. General Marine Indus., 695 A.2d 264 (N.J. 1997); Danforth v. Acorn Structures, Inc., 608 A.2d 1194, 1194 (Del. 1991).

51. Sapp v. Ford Motor Co., 687 S.E.2d 47, 49 (S.C. 2009); Sensenbrenner v. Rust, Orling \& Neal, Architects, Inc., 236 Va. 419 (Va. 1988).

52. Equistar Chems. v. Dresser-Rand Co., 240 S.W.3d 864 (Tex. 2007).

53. State Farm Mut. Auto. Ins. Co. v. Ford Motor Co., 736 So. 2d 384, 387 (Miss. Ct. App. 1999).

54. Neibarger v. Universal Cooperatives, Inc., 486 N.W.2d 612, 613 (Mich. 1992); Lincoln Gen. Ins. Co. v. Detroit Diesel Corp., 293 S.W.3d 487, 488 (Tenn. 2009); Presnell Constr. Managers, Inc. v. EH Constr., 134 S.W.3d 575, 584 (Ky. 2004) (acknowledging but not applying economic loss rule in products liability cases).

55. Gunkel, 822 N.E.2d at 151; Trans States Airlines v. Pratt \& Whitney Can., 177 Ill. 2d 21 (Ill. 1997). 
East River approach, including Missouri, Minnesota, South Dakota, and North Dakota. ${ }^{56}$ While the Supreme Court of Nebraska has not explicitly accepted the economic loss doctrine by name, it has followed the theory in application. ${ }^{57}$ In the Ninth Circuit, more states apply exceptions, with only three of the nine states (California, Nevada, and Washington) choosing to accept the economic loss theory without allowing for any such exceptions. ${ }^{58}$ All six states within the Tenth Circuit follow the majority rule. ${ }^{59}$ It should be noted that, while Oklahoma does not explicitly refer to its rule as the "economic loss doctrine," the theory laid out by the state Supreme Court is identical to this rule. ${ }^{60}$ Finally, all courts in the Eleventh Circuit, including the District of Columbia, have decided to follow the majority approach. ${ }^{61}$

As this illustrates, a majority of the highest state courts have chosen to follow the economic loss doctrine. The states following an exception, listed and explained in the following section, still accept the basic principle that the standard rule uses to create the line between tort and contract. Despite this

56. Sharp Bros. Contracting Co. v. American Hoist \& Derrick Co., 703 S.W.2d 901, 903 (Mo. 1986) (adopting the doctrine without calling it by name); $80 \mathrm{~S}$. Eighth St. Ltd. P'ship v. Carey-Canada, Inc., 486 N.W.2d 393, 396 (Minn. 1992); Steiner v. Ford Motor Co., 606 N.W.2d 881, $883-84$ (N.D. 2000); Diamond Surface v. State Cement Plant Comm'n, 583 N.W.2d 155, 160 (S.D. 1998).

57. Nat'l Crane Corp. v. Ohio Steel Tube Co., 332 N.W.2d 39, 42 (Neb. 1983) (holding that "the purchaser of a product pursuant to contract cannot recover economic losses from the manufacturer on claims based on principles of tort law, in the absence of property damage or personal injury from the use of the product").

58. Terracon Consultants W., Inc. v. Mandalay Resort Grp, 206 P.3d 81, 86 (Nev. 2009); Alejandre v. Bull, 153 P.3d 864, 868 (Wash. 2007); Jimenez v. Superior Court, 58 P.3d 450, 459 (Cal. 2002). Note that, while the California Supreme Court has taken an exception to the rule for independent duty, it has only applied this to professional liability suits. Robinson Helicopter Co., Inc. v. Dana Corp., 102 P.3d 268, 273 (Cal. 2004).

59. Amrep Sw. v. Shollenbarger Wood Treating Inc., 893 P.2d 438, 446 (N.M. 1995); Oklahoma Gas \& Electric Co. v. McGraw-Edison Co., 834 P.2d 980, 982 (Okla. 1992); D\&D Transp., Ltd. v. Interline Energy Servs., Inc., 117 P.3d 423, 427 (Wyo. 2005); Town of Alma v. Azco Constr., Inc., 10 P.3d 1256, 1259 (Colo. 2000) (applying the economic loss doctrine to a professional liability claim but discussing its origin in products liability); SME Indus., Inc. v. Thompson, Ventulett, Stainback \& Assocs., Inc., 28 P.3d 669, 680 (Utah 2001) (applying economic loss doctrine to professional liability case but acknowledging its application in products liability claims); Prendiville v. Contemporary Homes, Inc., 83 P.3d 1257 (Kan. Ct. App. 2004). Note that this Kansas appellate case discusses the doctrine in great detail. While the Supreme Court has acknowledged its acceptance of the rule, it has not gone into this great of detail as to its application in Kansas courts. Dieker v. Case Corp., 73 P.3d 133, 145 (Kan. 2003); see also Unruh v. Purina Mills, 221 P.3d 1130, 1138 (Kan. 2009).

60. Waggoner v. Town \& Cnty. Mobile Homes, Inc., 808 P.2d 649, 653 (Okla. 1990) (holding that "purely economic losses are not recoverable in products liability.")

61. Public Bldg. Auth. v. St. Paul Fire and Marine Ins. Co., 2010 Ala. LEXIS 198, at *33 (Ala. 2010); RLI Ins. Co. v. Pohl, Inc., 468 F. Supp. 2d 91, 94 (D. DC 2006); Airport Rent-a-Car, 660 So. 2d at 630; General Electric Co. v. Lowe's Home Centers, Inc., 608 S.E.2d 636, 637 (Ga. 2005). 
clear majority approach, there are still a small number of states that have decided not to adopt the economic loss doctrine. Aside from Pennsylvania, the courts that have refused to adopt the doctrine include Arkansas, Louisiana, and Montana. ${ }^{62}$ A number of appellate courts in North Carolina have used the economic loss doctrine, but its application has not yet been addressed by the state Supreme Court. ${ }^{63}$ The same is true of Iowa. ${ }^{64}$ The Supreme Court of Maryland has also not yet addressed this issue. ${ }^{65}$

In addition, while numerous appellate courts in Arizona have applied the doctrine without exception, ${ }^{66}$ its Supreme Court recently confirmed that while there are no exceptions to the rule as applied to professional liability, it has declined to bar all tort claims for economic losses in the case of products liability. ${ }^{67}$ Ohio has created a slightly confusing standard. While courts deciding both products liability and professional liability cases have claimed to follow the economic loss rule, the Ohio Supreme Court has strayed from the majority definition of what exactly "economic loss" consists. While plaintiffs are not permitted to bring negligence claims for economic loss, the court has limited this to cases where there is absolutely no physical damage. ${ }^{68}$ If there is any property damage, including that to the product itself, a claimant may sue for tort recovery. ${ }^{69}$ Therefore, while Ohio has seemingly adopted the doctrine in name, its definition removes it from the general standard of economic loss followed by the majority of courts in other states.

\section{EXCEPTIONS}

Courts have chosen to follow various exceptions when applying the economic loss rule. While they all still follow the general tort/contract distinction, these exceptions allow for tort recovery for damage to a purchased product in certain, limited circumstances. Some courts base this reasoning on an independent duty that is owed to the plaintiff outside of the contract.

62. No state case or federal case applying state law has been found applying this situation to a case in Montana and Louisiana.

63. Hospira Inc. v. AlphaGary Corp., 671 S.E.2d 7 (N.C. Ct. App. 2009); see also Lord v. Customized Consulting Specialty, Inc., 643 S.E.2d 28 (N.C. Ct. App. 2007).

64. Richards v. Midland Brick Sales Co., 551 N.W.2d 649 (Iowa 1996).

65. A search of Maryland case law did not result in a finding of any cases addressing the economic loss doctrine or the line between contract and tort claims in the highest court of that state.

66. Miidas Greenhouses v. Global Horticultural, Inc., 244 P.3d 579 (Ariz. Ct. App. 2010).

67. Flagstaff Affordable Hous. v. Design Alliance, Inc., 223 P.3d 664, 668 (Ariz. 2010).

68. Chemtrol Adhesives, Inc. v. American Mfrs. Mut. Ins. Co., 537 N.E.2d 624, 630 (Ohio 1989).

69. Id. 
Hawaii allows for an exception in cases involving negligent misrepresentation. ${ }^{70}$ West Virginia allows for an exception if there is a special relationship between the parties and a certain level of foreseeability. ${ }^{71}$ In addition, Wisconsin allows for an exception if there is fraud in the inducement. ${ }^{72}$ To properly allege that fraud in the inducement occurred, the plaintiff must show that the defendant intentionally made a misrepresentation that was prior to the contract and extraneous to the agreement. ${ }^{73}$ The courts of Idaho have allowed for exceptions to the general rule in cases with both a special relationship and "unique circumstances." 74 It is not explained exactly what circumstances will allow for this exception, but applying it calls for a reallocation of risk between the parties. ${ }^{75}$

Finally, exceptions have been created based not on the independent duty described above but on what actions or occurrences may, for policy reasons, create liability outside of the economic loss doctrine. Courts typically limit this exception to when the product has malfunctioned in a way that has created an unreasonably dangerous situation, or the risk of death or injury. ${ }^{76}$ This must also be accompanied by actual damage and loss, as not requiring this would make this exception too speculative. ${ }^{77}$

\section{“OTHER PROPERTY” DEFINITION}

While many states have accepted the economic loss doctrine in some form, general acceptance is not always enough to determine what the outcome may be in these cases. The original definition of economic loss focused on drawing the line between tort and contract based on whether damage occurred to the product itself. This definition requires a distinction between what the "product" is and what constitutes "other property." The Supreme Court took on a view followed by many states, while other courts have chosen to focus on either the original purchase or bargain. Still other state and federal courts focus specifically on certain component parts and their relation to the originally purchased item to determine what makes up the total product. This section does not exclusively include opinions from the highest courts for each

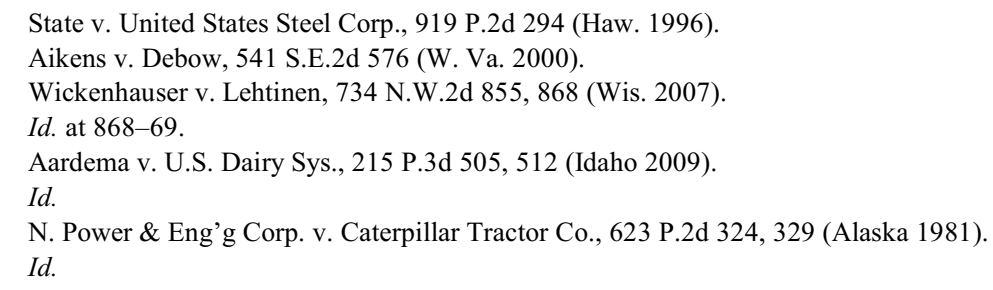


state. However, each case cited is at least at an appellate level, following highest court precedent for guidance on how the state's economic loss doctrine should be shaped. It should also be noted that not all states have taken a clear stance on this issue.

The Supreme Court addressed this issue in Saratoga Fishing Company v. J.M. Martinac \& Co., which was discussed briefly in a previous section. ${ }^{78}$ This case included a product that malfunctioned and harmed both itself and component parts that the purchaser had added after the original purchase. The Court held that these components, added after the initial purchase, were to be considered "other property" and, therefore, damage to them was recoverable in tort under the economic loss doctrine.$^{79}$ This is by far the clearest standard for distinguishing between the "product" and "other property," as it does not require any discretion in making the distinction. The "product" is simply defined by what was purchased and can easily be identified by the contract made by the parties.

When approaching this issue, courts will often follow the approach taken in Saratoga Fishing, but substitute different vernacular for the ideas encompassed in this theory. Instead of the above language, some have described looking to "the bargained for item" in determining what should be considered "other property." ${ }^{80}$ Courts using this language have looked to what was purchased by the buyer as a whole in determining what makes up the "product." 81 Indiana has chosen to label this approach as defining "the 'product' [as] the product purchased by the plaintiff, not the product furnished by the defendant." ${ }^{\prime 2}$ This allows for component parts purchased with the original product to be integrated into that product and not to be defined as "other property." This definition has been followed by both circuit courts and state courts. ${ }^{83}$ In contrast, the Arizona Court of Appeals has looked not to

78. Saratoga Fishing Co., 520 U.S. 875; see "The Economic Loss Doctrine," supra p. 827.

79. Id. at 879 .

80. McKenna v. The Terminex Int'1 Co., No. 04C-02-022, 2006 De. Super. LEXIS 551 (Del. Super. Ct. 2006); see also AIG Aviation, Inc. v. Bell Helicopter Textron, Inc., No. 95-16855, 1997 U.S. App. LEXIS 5390 (9th Cir. 1997); Trans State Airlines v. Pratt \& Whitney Canada, Inc., 177 Ill. 2d 21 (Ill. 1997); Davencourt at Pilgrims Landing Homeowners Ass'n v. Davencourt at Pilgrims Landing, LLC, 221 P.3d 234 (Utah 2009); N. Power \& Eng'g Corp., 623 P.2d at 330; Pro Con, Inc. v. J\&B Drywall, Inc., No. 032063C, 2006 WL 392123 (Mass. Super. Jan. 31, 2006).

81. Comptech Int'l, Inc. v. Milam Commerce Park, Ltd., 753 So. 2d 1219, 1226 (Fla. 1999); Indianapolis-Marion Cnty. Pub. Library v. Charlier Clark \& Linard, P.C., 929 N.E.2d 722, 731 (Ind. 2010); Indus. Risk Insurers v. Giddings \& Lewis, Inc., No. 2007-CA-002163-MR, 2009 Ky. App. LEXIS 106 at *21 (Ky. Ct. App. 2009).

82. Gunkel, 822 N.E.2d at 155 .

83. Mt. Lebanon Pers. Care Home, Inc. v. Hoover Universal, Inc., 276 F.3d 845 (6th Cir. 2002); see 
whether the parts were components, but rather if they were bought from the same or different suppliers. ${ }^{84}$

Courts taking the opposite approach to the "other property" question are not rare. Components added even after the original purchase are often considered a part of an integrated whole of the original product. ${ }^{85}$ Nevada and Tennessee have explained the policy behind this by citing to East River ${ }^{86}$ Due the fact that nearly all products have some sort of component to them, allowing for economic losses in cases of damage to those components would result in property damage, and allow for tort recovery in every products liability case. ${ }^{87} \mathrm{New}$ Jersey has adopted what it calls the "integrated product doctrine," which disallows recovery for economic losses even when the "product is incorporated into another product which the defective product then damages." 88

Some courts have gone further, expanding this scope by adopting what can be called the "foreseeability doctrine." This has been described as requiring the decision-maker to decide "whether the defective part is a sufficiently discrete element of the larger product that it is not reasonable to expect its failure invariably to damage other portions of the finished product." 89 That is, jurisdictions applying this doctrine do not simply look at what was purchased or originally a part of the product, but rather what the parties could have reasonably foreseen as being attached to that original product so that damage to that component would be inevitable following the failure of the product..$^{90}$ The theory behind this approach is that if the parties could have foreseen the integration at the time of the contract, "the remedy lies in contract, since the loss relates to a consumer's disappointed expectations due to deterioration, internal breakdown or non-accidental cause." $" 91$

also Oceanside at Pine Point Condo. Owners Ass'n, 659 A.2d 267 (Me. 1995); Pulte Home Corp. v. Parex, Inc., 923 A.2d 971, 1004 (Md. Ct. Spec. App. 2007).

84. Miidas Greenhouses, 244 P.3d 579.

85. Prendiville, 83 P.3d 1257; see also State Farm Mut. Auto. Ins. Co. v. Ford Motor Co., 736 So. 2d 384 (Miss. 1999); AKV Auto Transp., Inc. v. Syosset Truck Sales, Inc., 24 A.D.3d 833 (N.Y. App. Div. 2005); Land v. Tall House Bldg. Co., 602 S.E.2d 1, 4 (N.C. Ct. App. 2004).

86. Nat'l Union Fire Ins. Co. v. Pratt \& Whitney Can., Inc., 815 P.2d 601, 604 (Nev. 1991); Messer Griesheim Indus. v. Cryotech of Kingsport, Inc., 131 S.W.3d 457, 464 (Tenn. Ct. App. 2003).

87. Nat'l Union Fire Ins. Co., 815 P.2d at 604; Messer Griesheim Indus., 131 S.W.3d at 464.

88. Dean v. Barrett Homes, Inc., 8 A.3d 766, 773 (N.J. 2010).

89. KB Home v. Superior Court of Los Angeles Cnty., 5 Cal. Rptr. 3d 587, 596 (Ct. App. 2003).

90. Neibarger, 486 N.W.2d 612.

91. Richards, 551 N.W.2d at 651 (citing Nelson v. Todd's, Ltd., 426 N.W.2d 120, 125 (Iowa 1988)). 


\section{POLICY}

In order to make a suggestion for Pennsylvania, it will be advantageous to first look at both the policy and goals behind both the economic loss doctrine and the "gist of the action" doctrine. Doing so will assist in ensuring that the policy concerns of the "gist of the action" doctrine will be met even if it is abandoned in favor of the economic loss doctrine. A proper approach to the line between contract and tort can then be determined, while still following the policy that Superior Court panels in Pennsylvania have cited in products liability cases. ${ }^{92}$ Looking to these policy concerns will also assist in determining if there should be any exceptions to a standard Pennsylvania rule as well as determining a proper definition for "other property."

When applying the "gist of the action" doctrine, the Superior Court has held that, in drawing the line between contract and tort, it is "concerned with the nature of the action as a whole." ${ }^{93}$ In determining whether the claim "sounds" in contract or tort, the District Court for the Eastern District has held that "if the duties in question are intertwined with contractual obligations, the claim sounds in contract, but if the duties are collateral to the contract, the claim sounds in tort." 94 To further demonstrate the unclear standard in Pennsylvania, the court made this holding while simultaneously stating that this was the approach for the economic loss doctrine and that it should be adopted under that name. ${ }^{95}$ Even more puzzling, the same court also advocated for the "gist of the action" doctrine, defining it as "prohibit[ing][tort] claims where the duties essentially flow from an agreement between the parties." 96 This makes the goal and policies of the Commonwealth even more unclear.

One must decide whether the action sounds in contract or tort in order to decide what duties are owed to the purchaser. As stated previously, under the "gist of the action" doctrine:

[t]he critical conceptual distinction between a breach of contract claims and a tort claim is that the former arises out of "breaches of duties imposed by mutual

92. Each appeal to the Superior Court is assigned and decided by a panel of three judges. Superior Court of Pennsylvania Internal Operating Procedures $\S 65.5$.

93. Erie Ins. Exch. v. Abbott Furnace Co., 972 A.2d at 1238

94. Knit With v. Knitting Fever, Inc., Nos. 08-4221, 08-4775, 2009 WL 3427054, at *5 (E.D. Pa. Oct. 20, 2009).

95. Id.

96. Id. at $* 17$. 
consensus agreements between particular individuals," while the latter arises out of "breaches of duties imposed by law as a matter of social policy." 97

As listed in a previous section, there is also the possibility of applying the misfeasance/nonfeasance test. ${ }^{98}$

It is clear from all of these decisions that there is not one way to distinguish the line between contract and torts in Pennsylvania, even if all courts choose to apply the "gist of the action" doctrine and it is adopted by the Supreme Court of Pennsylvania. While all seem to point in the same direction, some are far less clear than others, giving the courts no clear standard. It is not a general test and the level of discretion necessary results in conflicting decisions among Pennsylvania courts. In addition, all of these standards only frustrate the possibility of settlements - a policy in any jurisdiction-as there is no predictability as to what a litigant may face in court. It is even difficult to see the policy behind these decisions other than attempting to draw a distinction between tort and contract claims and preclude the former when unnecessary to protect the injured party. At most, these cases show that Pennsylvania courts applying the "gist of the action" doctrine are seeking a way to draw the line between contract and tort to make sure that the duties owed in each situation are kept separate, and that tort obligations do not spill over into mere contract cases. This can be accomplished by adopting the clearer standard of the economic loss doctrine.

To determine the policy behind the economic loss doctrine, it is best to start at its origin. In the case held by many courts to be the starting point for this theory, it was noted that manufacturers may "appropriately be held liable for physical injuries caused by defects by requiring his goods to match a standard of safety defined in terms of conditions that create unreasonable risks of harm." ${ }^{\circ 9}$ If this is the case, an injured party may file suit against them in a tort claim. However, the court held that the manufacturer or selling party "cannot be held for the level of performance of his products in the consumer's business unless he agrees that the product was designed to meet the consumer's demands." 100 This puts a heavy weight on the rights that each party can guarantee itself through the bargaining process.

Courts have further expanded on the policy behind applying the doctrine. One such reason is the possible frustration of UCC provisions. If plaintiffs

97. Erie Ins. Exch., 972 A.2d at 1238 (citing Reardon, 926 A.2d at 486-87).

98. See "Current State of Pennsylvania Law," supra p. 829.

99. Seely, 403 P.2d at 151.

100. $I d$. 
could sue in tort under contract claims that may have been covered during bargaining, "UCC provisions designed to govern such disputes, which allow limitation or elimination of warranties and consequential damages, require notice to the seller, and limit the time in which such a suit must be filed, could be entirely avoided." 101 Because warranties allow for contract claims in the case of a product that does not live up to economic expectations and causes only economic harm, "“[t]o allow tort liability in commercial transactions would totally emasculate [the warranty] provisions of the U.C.C." ${ }^{102} \mathrm{Put}$ plainly, "[g]iven the availability of warranties, the courts should not ask tort law to perform a job that contract law might perform better." 103

Finally, policies similar to those listed by Pennsylvania courts have also been listed as reasons for the economic loss doctrine. The Supreme Court of Michigan held, in applying the doctrine that "the individual consumer's tort remedy for products liability is not premised upon an agreement between the parties, but derives either from a duty imposed by law or from policy considerations which allocate the risk of dangerous and unsafe products to the manufacturer and seller rather than the consumer." 104 This focus on duties comports with the reasoning used by Pennsylvania courts.

\section{RECOMMENDATION FOR PENNSYLVANIA}

The previous section shows that the policies listed in prior Pennsylvania cases can be met by adopting the economic loss doctrine. In addition to policy, another important point to focus on is administrability. In looking at Pennsylvania cases, it is clear that courts have very different ideas of the standard that should be applied in these cases. By picking the clearest standard possible, it will make the determination of cases simpler for the courts and more predictable for possible litigants. It is clear that adopting the economic loss doctrine in Pennsylvania will allow its courts to follow the policies listed in Erie Insurance Exchange and other cases. Allowing tort recovery for damage to persons or other property will not disrupt the holding that "a third party's complaint alleging only faulty workmanship and damage to the

101. Neibarger, 486 N.W.2d at 616.

102. 80 S. Eighth St. L.P. v. Carey-Canada, Inc., 486 N.W.2d 393, 396 (Minn. 1992) (citing Superwood Corp. v. Siemelkamp Corp., 311 N.W.2d 159 (Minn. 1981)).

103. Saratoga Fishing Co., 520 U.S. at 880.

104. Neibarger, 486 N.W.2d at 616. 
insured's work product" does not allow for tort recovery. ${ }^{105}$ A party claiming only economic losses such as this will not be allowed to recover in tort.

The previously discussed definitions of economic loss neatly address the concerns of the Superior Court. ${ }^{106}$ Put simply, "[1]imiting tort liability when the contract exists between parties is appropriate because a product's potential nonperformance can be adequately addressed by rational economic actors bargaining at arm's length to shape the terms of the contract." ${ }^{107}$ Parties can recover for disappointed expectations and damage to the purchased product through contract claims. Damage to people and all other property is appropriately within the realm of torts.

The Pennsylvania Uniform Commercial Code provisions covering warranty disputes are sufficient to guide these breach of contract claims. ${ }^{108}$ Among these sections are the implied warranty of merchantability and the implied warranty of fitness for a particular purpose. ${ }^{109}$ As discussed previously, not adopting the economic loss doctrine may frustrate these warranties. The court in Erie Insurance Exchange held that "contractual claims of poor workmanship do not constitute the active malfunctioning needed to establish coverage under a general liability policy," namely that they do not constitute a tort. ${ }^{110}$ This faulty workmanship can be seen as a breach of warranty. If it were a breach of the implied warranty of fitness, it may, as the statute reads, be accounted for at the time the contract is made. ${ }^{111}$ The parties can contract for this sort of faulty workmanship to ensure that the product will be "fit for the ordinary purposes for which such goods are used." "If If it malfunctions in that ordinary use, the implied warranty of fitness will cover damage resulting to the product, and will have been bargained for at the time of contracting. From these provisions and other contract principles, it is clear that the protections meant for Pennsylvania buyers can continue to be available without allowing for tort recovery outside of the constraints of the economic loss doctrine.

Once damages go outside of the realm of faulty workmanship or breach of contract, they will be recoverable in tort. A claim for damage to a person or property is not merely "the failure of the purchaser to receive the benefit of

105. Erie Ins. Exch., 972 A.2d at 1237.

106. See "The Economic Loss Doctrine," supra p. 827.

107. Town of Alma, Colorado v. Azco Constr., Inc., 10 P.3d 1256, 1262 (Colo. 2000).

108. 13 Pa. Cons. Stat. $\S 2313-18$ (2006).

109. 13 Pa. Cons. Stat. $\S \S 2314$ (b), 2315 (2006).

110. Erie Ins. Exch., 972 A.2d at 1238.

111. 13 Pa. Cons. STAT. $\$ 2315$ (2006).

112. 13 Pa. Cons. STAt. $§ 2314($ b)(3) (2006). 
its bargain." 113 This will address another major focus by the Pennsylvania Superior Court, namely the duties enforced under the law of torts. ${ }^{114}$ The court looked to "duties imposed by law as a matter of social policy." economic losses are those that could have been covered for in the original bargaining process, they will fall under the Pennsylvania version of the UCC warranty provisions. ${ }^{116}$ However, when product failure results in harm to other property or persons, these are not typically considered to be occurrences that may have been foreseen at the time the contract was made. Social policy then calls for manufacturers to be liable in tort in these circumstances. On the contrary, the "gist of the action" doctrine has led courts to find that tort recovery is only available when "the tortious conduct was the 'gist' of the action and the contract was merely collateral to the conduct." 117 In a way, this frustrates the policies of tort by not providing adequate redress for purchasers injured by manufacturers' products in situations from which they could not have bargained for protection.

Finally, if Pennsylvania follows the economic loss doctrine, it must also decide whether or not to follow the Saratoga Fishing Co. definition of "other property." 118 As stated, this case provides the clearest standard for deciding this question. ${ }^{119}$ It will not require any discretion for the court to determine what the definition of the "product" should be. The court must only look at the terms of the contract, which will explicitly provide what was originally purchased. However, in looking at the policies of the Pennsylvania Superior Court, it may be advisable instead to use the foreseeability doctrine. ${ }^{120}$

The foreseeability doctrine will address the issue of overwhelming liability on manufacturers. Pennsylvania courts have been concerned with this issue and may agree with a New Jersey court's holding that "[a]llowing recovery for all foreseeable damages in claims seeking purely economic loss, could subject a manufacturer to liability for vast sums arising from the expectations of parties downstream in the chain of distribution." 121 While this 2006)

113. McKenna v. Terminex Int'l Co., 2006 De. Super. LEXIS 551, at *10 (Del. Super. Ct. Mar. 13,

114. See generally Erie Ins. Exch., 972 A.2d at 1232.

115. Id. at 1238 .

116. 13 PA. Cons. STAT. $\S 2313-18$ (2006).

117. Erie Ins. Exch., 972 A.2d at 1239.

118. Saratoga Fishing Co., 520 U.S. 875.

119. See “"Other Property' Definition," supra p. 836.

120. See generally Richards, 551 N.W.2d 649.

121. Alloway v. Gen. Marine Indus., 695 A.2d 264 (N.J. 1997); see generally Knit With, 2009 WL 3427054 . 
will require more discretion, it will allow for Pennsylvania courts to bar tort recovery for damage to property that was foreseeable at the time of the contract when considering potential consequences if the product itself malfunctioned or harmed itself. This will clearly draw the line between contract and tort and not allow for tort damages when the damage was foreseeable, as the parties could have bargained for this loss at the creation of the contract.

\section{CONCLUSION}

The Supreme Court of Pennsylvania must make a decision on this issue and adopt a standard for distinguishing between tort and contract claims in products liability cases. Pennsylvania courts have become an unclear forum for products liability claims, as courts across the state are following different standards for deciding these questions. A majority of the highest courts in other jurisdictions have reviewed this question, with most choosing to accept the economic loss doctrine. Based on the policy concerns of Pennsylvania courts, it would be advisable to accept the economic loss doctrine, as the majority of other jurisdictions have accepted it. This will allow for uniformity in decisions, predictability for litigants, and a possible higher likelihood of settlements for litigants who can better foresee what they may encounter in court. 